(2) Open Access Full Text Article

CASE REPORT

\title{
A rare case of myxoid liposarcoma of the adult foot diagnosed using fine needle aspiration cytology (FNAC)
}

This article was published in the following Dove Press journal:

Pathology and Laboratory Medicine International

31 December 2014

Number of times this article has been viewed

\section{Shoko Kure' \\ Wei-Xia Peng' \\ Mitsuhiro Kudo' \\ Miyuki Matsubara ${ }^{2}$ \\ Takashi Tsunoda ${ }^{3}$ \\ Zenya Naito ${ }^{1,2}$}

'Department of Integrated Diagnostic Pathology, Nippon Medical School, ${ }^{2}$ Department of Pathology, Nippon Medical School Hospital, ${ }^{3}$ Department of Orthopedics, Nippon Medical School Department of Orthopedics, Nippon Medical School, Tokyo, Japan

Correspondence: Zenya Naito Department of Integrated Diagnostic Pathology, Nippon Medical School, Department of Pathology, Nippon Medical School Hospital, I-I-5 Sendagi, Bunkyo-ku, Tokyo II 3-8602, Japan Tel $+8 \mid 338222131$ ext 5232

$\mathrm{Fax}+8$ I 356853067

Email naito@nms.ac.jp

\begin{abstract}
Liposarcoma is categorized as a soft tissue sarcoma that most commonly appears in the lower extremities during adulthood, but rarely in the feet. We present a rare case of a primary myxoid liposarcoma in the foot of a 63 -year-old man that was diagnosed by fine needle aspiration cytology (FNAC). The patient presented to our hospital with a 10-year history of a slow-growing mass on the left lateral ankle. On physical examination, the $60 \mathrm{~mm} \times 60 \mathrm{~mm}$ mass, was found to be soft and elastic, causing poor mobility without pain. Magnetic resonance imaging of the mass revealed high signal intensity on T1-weighted images and heterogeneously high signal intensity on T2-weighted images without fat suppression. As a result of the physical examination and imaging, the mass was suspected to be a lipoma or ganglion cyst. However, the FNAC procedure revealed atypical small, round, short spindle cells, or foamy cells with a myxoid background, suggesting myxoid liposarcoma. Histology using an open biopsy showed a proliferation of atypical spindle and asteroid cells with a few foamy lipoblasts in a capillary-rich and myxoid background. The atypical lipoblasts were slightly positive for S-100. These findings were consistent with myxoid liposarcoma. The patient was treated with a resection of the mass. Liposarcoma is considered to be the second most common soft-tissue sarcoma. It usually involves the lower extremities, particularly the thigh, and is very rare in the adult foot. Our case was a rare occurrence of myxoid liposarcoma of the foot diagnosed preoperatively using FNAC.
\end{abstract}

Keywords: myxoid liposarcoma, foot, fine needle aspiration cytology (FNAC), adult

\section{Introduction}

In more than $50 \%$ of cases of soft tissue sarcomas in the foot, the difficulty of making a preoperative diagnosis has resulted in unplanned surgical resections. ${ }^{1-3}$ However, the ability to make a preoperative diagnosis is important, since resections of the foot mass can be limb/foot threatening.

According to a previous study, liposarcoma is the second most common sarcoma after malignant fibrous histocytoma. ${ }^{4}$ Approximately $68 \%-74 \%$ of liposarcomas occur in the lower extremities. They are most frequently found in the thigh (40\%), and rarely found in the foot $(1.3 \%-2.7 \%)$ or leg $(6.7 \%-13.5 \%){ }^{4-11}$ Reports of myxoid liposarcoma in the foot are very limited.

Our case involved a 63-year-old man with a myxoid liposarcoma in the foot that was diagnosed preoperatively using fine needle aspiration cytology (FNAC).

\section{Case report}

A 63-year-old man presented to our hospital with a painless mass in the left lateral ankle that had been slowly growing over a period of 10 years. He had no history of trauma 
and no remarkable medical history. A physical examination revealed a soft, elastic mass measuring approximately $6.0 \mathrm{~cm} \times 6.0 \mathrm{~cm}$ and causing poor mobility. A plain radiograph showed a soft tissue mass in the form of increased soft tissue density without calcification or osseous involvement. Magnetic resonance imaging (MRI) indicated a well-defined and multilobular mass within the subcutaneous tissue of the ankle. T1-weighted images showed low signal intensity with foci of linear high signal intensity (Figure 1A). On T2-weighted images, the mass showed heterogeneously high signal intensity (Figure 1B). The mass was not suppressed by fat suppression images. Positron emission tomography showed no metastasis or other lesions. There were no remarkable findings in the blood test. This clinical information suggested that the mass was a ganglion cyst.

The next procedure performed was FNAC (Figure 2). The aspirate smears revealed scattered cellular clusters. They contained dyscohesive, atypical small, round cells and short spindle cells (Figure 2A). These cells had enlarged and oval nuclei with coarse chromatin. However, the cells demonstrated rare mitotic features. The extracellular matrix was rich in hyaluronic acid. A fine plexiform capillary network was also observed. Only a few foamy cells were noticeable, so it was difficult to determine if they were macrophages or lipoblasts (Figure 2B and C). These findings suggested a diagnosis of myxoid tumor. The histological type was not determined with the first FNAC.

Following this, the second FNAC was performed (Figure 3). The specimen contained a vascular network with a myxoid background (Figure 3A). It revealed more atypical vacuolated cells (Figure 3B-D). These vacuolated cells had a spider web appearance and were identified as lipoblasts. The resultant diagnosis after this test was myxoid liposarcoma. The patient subsequently underwent an open biopsy to confirm the diagnosis.

The open biopsy specimen was an irregular, oblong soft tissue mass. The gross findings indicated that the mass
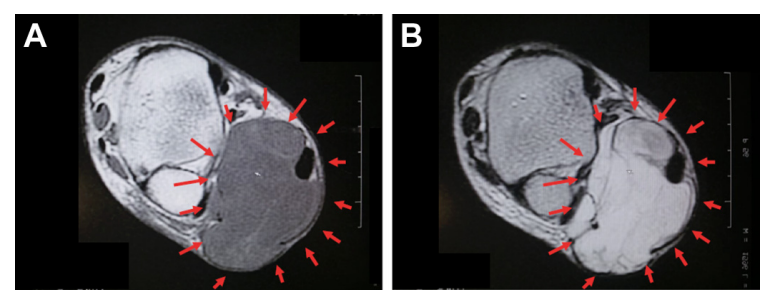

Figure I TI-weighted images.

Notes: (A) Magnetic resonance imaging revealed a well-defined and multilobular mass within the subcutaneous tissue of the ankle (arrows). TI-weighted images show low signal intensity with foci of linear high signal intensity. (B) The mass shows heterogeneously high signal intensity without fat suppression (arrows).

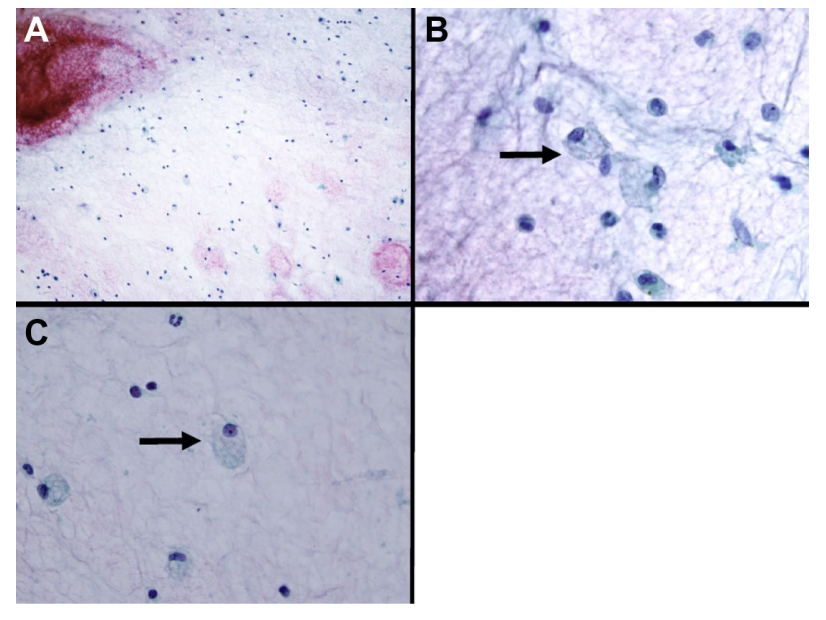

Figure 2 The first fine needle aspiration cytology.

Notes: (A) The specimen contains dyscohesive, atypical small, round cells and short spindle cells. The extracellular matrix is rich in hyaluronic acid, and a fine plexiform capillary network is also observed (papanicolaou, $\times 200$ ). (B) Large, foamy, round cells with enlarged and hyperchromatic oval nuclei can be seen but they are few in number (arrow) (papanicolaou, $\times 600$ ). (C) The specimen contains foamy cells, but it is difficult to determine if they were macrophages or lipoblasts. The first fine needle aspiration cytology leads to a diagnosis of myxoid tumor (arrow) (papanicolaou, $\times 600$ ).

was bright yellow in color and the external surface was a glistening serous membrane blending into a fibrous fascial membrane in certain areas. The surface was of a mucoid gross texture colored dark yellow due to the presence of bleeding. Histologically, the specimen contained myxoid stroma positive for alcian blue staining (Figure 4A), and an arborizing capillary vasculature. The specimen showed a proliferation of atypical, short spindle cells with some atypical lipoblasts (Figure 4B and C). These lipoblasts were positive for S-100 (Figure 4D). The Ki-67 labeling index was 20\%. The tumor cells were negative for cytokeratin (AE1/AE3) stains, epithelial membrane antigen, human melanoma black 45, Melan

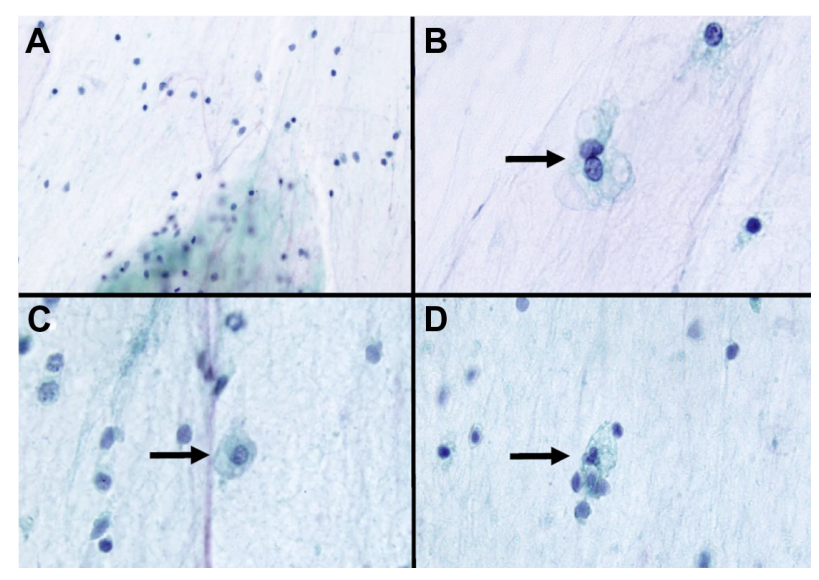

Figure 3 The second fine needle aspiration cytology specimen.

Notes: (A) The specimen contains a small vascular network and myxoid background (papanicolaou, $\times 200$ ). (B-D) The specimen contains more vacuolated cells, forming a spiderweb appearance.These cells are identified as lipoblasts (arrows) (papanicolaou, $\times 600$ ). 


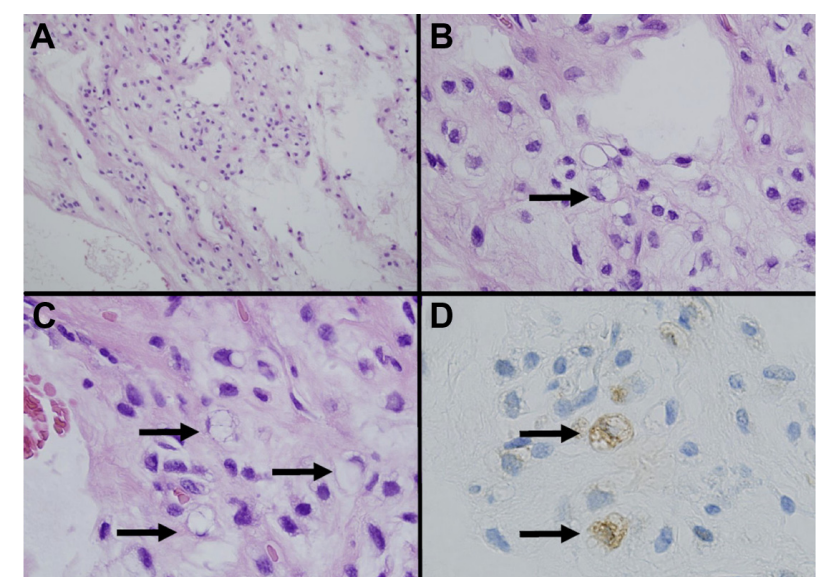

Figure 4 Open biopsy specimen.

Notes: (A) Hematoxylin and eosin staining specimen shows a proliferation of atypical spindle and asteroid cells with a few foamy lipoblasts in a capillary-rich and myxoid background (hematoxylin and eosin, $\times 200$ ). (B and C) The specimen contains lipoblasts with small vacuoles (arrows) (hematoxylin and eosin, $\times 600$ ). (D) The lipoblasts are faintly positive for S- 100 (arrows) $(S-100, \times 600)$.

A, alpha smooth muscle Actin, desmin, cluster of differentiation 10, and cluster of differentiation 68 . The pathological diagnosis resulting from the open biopsy was myxoid liposarcoma. A total resection of the mass was planned. As the mass compressed the gastrocnemius muscle and Achilles tendon, the surgeon also performed photodynamic and radiodynamic therapies ( $5 \mathrm{~Gy}$ ) with acridine orange, in view of the risks posed by a total resection with a wide margin. The surgical specimen was a $6 \mathrm{~cm}$ gelatinous soft mass. The final diagnosis was myxoid liposarcoma and the final stage was T1aN0M0.

\section{Discussion}

According to previous reports, the difficulty in making a preoperative diagnosis has resulted in unplanned surgical resections being performed in more than $50 \%$ of patients with soft tissue sarcomas of the foot or ankle. ${ }^{1-3}$ Thus, preoperative diagnosis of liposarcoma in the foot is particularly important, because resection can be limb threatening. However, cytologically, it is difficult to distinguish liposarcoma from other soft tissue tumors because of overlapping histological features, especially on limited tissue samples. Clinically, myxoid liposarcomas show a similar MRI pattern to that of ganglions. Ganglions, which are filled with fluid, show a low signal intensity on T1-weighted sequences and high signal intensity on T2-weighted sequences, and frequently occur in tendon sheaths and joints. Myxoid liposarcomas exhibit very similar MRI patterns. However, pathologically, ganglions have cystic lesions that are not observed in myxoid liposarcomas. The major point of differential diagnosis from the pathological viewpoint is that myxoid liposarcomas include myxoid malignant fibrous histocytomas, myxoid chondrosarcomas, dermatofibrosarcoma protuberans, and lipoblastomas. A myxoid malignant fibrous histocytoma contains pleomorphic vacuolated cells that tend to be misinterpreted as lipoblasts. The vacuoles of these "pseudolipoblasts" are large, poorly defined, and filled with hyaluronic acid rather than lipid. A myxoid chondrosarcoma consists of small, eosinophilic cells typically arranged in small clusters, cords, or pseudoacini. In contrast, myxoid liposarcomas show a single-cell arrangement. An extremely myxoid form of dermatofibrosarcoma protuberans can simulate myxoid liposarcoma. However, myxoid liposarcoma can be discounted due to the lack of lipoblasts and its superficial location. ${ }^{10,11}$ Lipoblastoma usually occurs in childhood, and contains no atypical lipoblasts. ${ }^{12}$ In these cases, immunohistochemistry of S-100 is a helpful tool in providing a diagnosis.

In our case, the histological type was "undetermined" in the first FNAC because of the lack of the typical lipoblasts. The second FNAC contained definitive atypical lipoblasts, vascular components, and a myxoid background, resulting in the diagnosis of myxoid liposarcoma.

Liposarcoma, the second most common sarcoma, usually occurs in the thigh or popliteal regions, and only rarely in the foot. ${ }^{6-9}$ Histologically, it is subdivided into the categories of "dedifferentiated," "myxoid," and "pleomorphic" type. The myxoid subtype accounts for $20 \%-50 \%$ of all liposarcomas. ${ }^{13}$ A pure myxoid liposarcoma is considered as a low-intermediate grade sarcoma, with a $90 \% 5$-year survival rate. ${ }^{14,15}$ Myxoid liposarcomas have chromosomal translocation of $\mathrm{t}(12 ; 16)$ (q13:p11) or more rarely $\mathrm{t}(12 ; 22)(\mathrm{q} 13: \mathrm{q} 12)$, producing a FUS-CHOP or EWSR1-CHOP fusion gene, respectively. The treatment of choice at present is complete tumor resection with a clear surgical margin. Previous reports have shown that patients with positive surgical margins bore a two-fold higher risk of dying from their disease and a 1.7-fold higher risk of developing local recurrence, compared to patients without positive margins. ${ }^{16}$ Myxoid liposarcoma is reportedly both chemosensitive and radiosensitive. Photodynamic therapy with acridine orange has recently been described as an alternative adjuvant therapy effective in reducing the surgical margin and improving limb function. ${ }^{17}$

The prognostic factors of myxoid liposarcoma discussed in the previous studies are summarized in Table 1. ${ }^{14,16,18,19}$ Kilpatrick et al have studied the clinicopathological features of 95 patients of myxoid/round cell liposarcoma. ${ }^{18}$ They showed that the percentage of round cell differentiation $(>25 \%)$, spontaneous tumor necrosis, and an age older than 
Table I Prognostic factors for myxoid liposarcoma

\begin{tabular}{|c|c|c|c|c|c|c|c|c|}
\hline \multirow{2}{*}{$\begin{array}{l}\text { Authorl } \\
\text { year }\end{array}$} & \multirow{2}{*}{$\begin{array}{l}\text { Number } \\
\text { of cases }\end{array}$} & \multirow[t]{2}{*}{ Age } & \multirow{2}{*}{$\begin{array}{l}\text { Tumor size } \\
(\geq 10 \mathrm{~cm})\end{array}$} & \multicolumn{2}{|c|}{ Round cell component } & \multirow[t]{2}{*}{ Necrosis } & \multirow{2}{*}{$\begin{array}{l}\text { TP53 positive } \\
\text { ( } \geq 10 \%)\end{array}$} & \multirow{2}{*}{$\begin{array}{l}\text { Positive surgical } \\
\text { margin }\end{array}$} \\
\hline & & & & $\geq \mathbf{5} \%$ & $\geq \mathbf{2 5} \%$ & & & \\
\hline $\begin{array}{l}\text { Kilpatrick } \\
\text { et al//1996 }\end{array}$ & 95 & $\begin{array}{l}\text { 5-year survival: } \\
<45 \text { years: } 88 \% \text {, } \\
\geq 45 \text { years: } 72 \%\end{array}$ & ND & ND & $\begin{array}{l}\text { 5-year survival: } \\
<25 \% 89 \% \\
\geq 25 \% 79 \%\end{array}$ & $\begin{array}{l}\text { 5-year survival: } \\
\text { necrosis(+) } 25 \% \text {, } \\
\text { necrosis(-) } 90 \%\end{array}$ & ND & ND \\
\hline $\begin{array}{l}\text { Antonescu } \\
\text { et } \mathrm{al} / 200 \mathrm{I}^{14}\end{array}$ & 82 & ND & NS & $\begin{array}{l}\text { Metastasis, } \\
\text { DSS }\end{array}$ & NS & Worse DSS & Metastasis & ND \\
\hline $\begin{array}{l}\text { Fiore et al/ } \\
2007^{16}\end{array}$ & 329 & ND & $\begin{array}{l}3.5 \text {-fold greater } \\
\text { risk of DSS }\end{array}$ & $\begin{array}{l}\text { Metastasis, } \\
\text { I.5-fold } \\
\text { greater } \\
\text { risk of DSS }\end{array}$ & ND & ND & ND & $\begin{array}{l}\text { Two-fold greater } \\
\text { risk of DSS } \\
\text { I.7-fold greater risk } \\
\text { of local recurrence }\end{array}$ \\
\hline $\begin{array}{l}\text { Asano } \\
\text { et al/2012 } 2^{19}\end{array}$ & 58 & ND & $\begin{array}{l}\text { Extrapulmonary } \\
\text { metastasis }\end{array}$ & Metastasis & ND & ND & ND & ND \\
\hline
\end{tabular}

Abbreviations: DSS, disease-specific survival; ND, not determined; NS, not significant.

45 years were all significantly associated with poor survival (Table 1). Another study by Fiore et al showed associations between the presence of a 5\% round cell component and a greater risk of metastasis or death (hazard ratio $2.98,95 \%$ confidence interval 1.62-5.48, $P=0.0005$; hazard ratio 1.65 , $95 \%$ confidence interval $0.92-2.97, P=0.0940$, respectively). ${ }^{16}$ Follow-up was required in the present case, as the round cell component was approximately 5\% and the patient was over 45 years of age.

Our case was a relatively rare occurrence of myxoid liposarcoma in the adult foot. Tumors in the foot can be limb threatening, and depending on the prognostic factors necessitate close follow-up for some patients. In the present case, a preoperative diagnosis was successfully achieved using FNAC, suggesting that this procedure is a helpful tool in cases of myxoid liposarcoma.

\section{Disclosure}

The authors report no conflicts of interest in this work.

\section{References}

1. Chou LB, Ho YY, Malawer MM. Tumors of the foot and ankle: experience with 153 cases. Foot Ankle Int. 2009;30(9):836-841.

2. Temple HT, Worman DS, Mnaymneh WA. Unplanned surgical excision of tumors of the foot and ankle. Cancer Control. 2001;8(3):262-268.

3. Thacker MM, Potter BK, Pitcher JD, Temple HT. Soft tissue sarcomas of the foot and ankle: impact of unplanned excision, limb salvage, and multimodality therapy. Foot Ankle Int. 2008;29(7):690-698.

4. Enzinger FM, Winslow DJ. Liposarcoma. A study of 103 cases. Virchows Arch Pathol Anat Physiol Klin Med. 1962;335:367-388.

5. Pack GT, Pierson JC. Liposarcoma; a study of 105 cases. Surgery. 1954;36(4):687-712.

6. Kransdorf MJ. Malignant soft-tissue tumors in a large referral population: distribution of diagnoses by age, sex, and location. AJR Am J Roentgenol. 1995;164(1):129-134.
7. Kudo H, Inaoka $\mathrm{T}$, Tokuyama $\mathrm{W}$, et al. Round cell liposarcoma arising in the left foot: MRI and PET findings. Jpn J Radiol. 2012;30(10):852-857.

8. Nishio J, Isayama T, Yoshimura I, Ohjimi H, Iwasaki H, Naito M. Myxoid liposarcoma of the ankle: a case report. J Foot Ankle Surg. 2011;51(1):76-79.

9. Thompson DE, Frost HM, Hendrick JW, Horn RC Jr. Soft tissue sarcomas involving the extremities and the limb girdles: a review. South Med J. 1971;64(1):33-44.

10. Werd MB, DeFronzo DJ, Landsman AS, Surprenant M, Sakoff M. Myxoid liposarcoma of the ankle. J Foot Ankle Surg. 1995;34(5):465-474.

11. Wu KK. Tumor review. Liposarcoma of the ankle. J Foot Surg. 1988; 27(3):276-280.

12. Nagano A, Ohno T, Nishimoto Y, Hirose Y, Miyake S, Shimizu K. Lipoblastoma mimicking myxoid liposarcoma: a clinical report and literature review. Tohoku J Exp Med. 2011;223(1):75-78.

13. Murphey MD, Arcara LK, Fanburg-Smith J. From the archives of the AFIP: imaging of musculoskeletal liposarcoma with radiologicpathologic correlation. Radiographics. 2005;25(5):1371-1395.

14. Antonescu CR, Tschernyavsky SJ, Decuseara R, et al. Prognostic impact of P53 status, TLS-CHOP fusion transcript structure, and histological grade in myxoid liposarcoma: a molecular and clinicopathologic study of 82 cases. Clin Cancer Res. 2001;7(12):3977-3987.

15. Nishida Y, Tsukushi S, Nakashima H, Ishiguro N. Clinicopathologic prognostic factors of pure myxoid liposarcoma of the extremities and trunk wall. Clin Orthop Relat Res. 2010;468(11):3041-3046.

16. Fiore M, Grosso F, Lo Vullo S, et al. Myxoid/round cell and pleomorphic liposarcomas: prognostic factors and survival in a series of patients treated at a single institution. Cancer. 2007;109(12):2522-2531.

17. Matsubara T, Kusuzaki K, Matsumine A, Nakamura T, Sudo A. Can a less radical surgery using photodynamic therapy with acridine orange be equal to a wide-margin resection? Clin Orthop Relat Res. 2013;471(3):792-802.

18. Kilpatrick SE, Doyon J, Choong PF, Sim FH, Nascimento AG. The clinicopathologic spectrum of myxoid and round cell liposarcoma. A study of 95 cases. Cancer. 1996;77(8):1450-1458.

19. Asano N, Susa M, Hosaka S, et al. Metastatic patterns of myxoid/ round cell liposarcoma: a review of a 25 -year experience. Sarcoma. 2012;2012:345161. 
Pathology and Laboratory Medicine International

\section{Publish your work in this journal}

Pathology and Laboratory Medicine International is a peer-reviewed, open access journal focusing on innovative basic research and translational research related to pathology or human disease. The journal includes original research, updates, case reports, reviews and commentaries on current controversies. The Academic Sponsor of this journal is the Chinese American Pathology Association (CAPA). The manuscript management system is completely online and includes a very quick and fair peer-review system. Visit http://www.dovepress.com/testimonials.php to read real quotes from published authors.

Submit your manuscript here: http://www.dovepress.com/pathology-and-laboratory-medicine-international-journal 